\title{
The seasonal dynamics of nutrient and chlorophyll $a$ concentrations on the SE Mediterranean shelf-slope
}

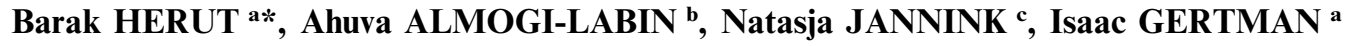 \\ ${ }^{\text {a }}$ Israel Oceanographic \& Limnological Research, National Institute of Oceanography, Haifa, 31080, Israel \\ ${ }^{\mathrm{b}}$ Geological Survey of Israel, 30 Malke Yisrael St., Jerusalem, 95501, Israel \\ ${ }^{\mathrm{c}}$ Institute of Earth Sciences, Budapestlaan 4, 3584 CD Utrecht, The Netherlands
}

Received 12 April 2000; accepted 7 July 2000

\begin{abstract}
We report the results of a sequence of twelve research cruises over a two-year period, from June 1996 through May 1998 that examined the seasonal variations in the nutrient $\left(\mathrm{NO}_{3}^{-}, \mathrm{PO}_{4}^{3-}\right.$, and $\left.\mathrm{Si}(\mathrm{OH})_{4}\right)$ and in the chlorophyll $a(\mathrm{Chl} a)$ concentrations at two permanent stations across the SE Mediterranean continental shelf and slope (120 and $400 \mathrm{~m}$ water depth off the Israeli coast). Seasonally-dependent $\mathrm{Chl} a$ concentrations ranged between 0.003 and $0.415 \mathrm{mg} \mathrm{m}^{-3}$. Following autumn and winter a distinct biomass phytoplankton peak was produced ( $\sim 30 \mathrm{mg} \mathrm{Chl} a \mathrm{~m}^{-2}$ in the upper $120 \mathrm{~m}$ ) and a subsequent moderate spring peak was observed. In the decomposition zone $(120-400 \mathrm{~m})$, an opposite pattern was observed with decreasing amounts of $\mathrm{NO}_{3}^{-}$and $\mathrm{PO}_{4}^{3-}$ during winter. The integrated $\mathrm{Si}(\mathrm{OH})_{4}$ pattern in the euphotic zone indicates that diatoms grow during spring and summer and that their frustules are rapidly settled during the breakdown of stratification. At depths between 150 and $400 \mathrm{~m}$, the geometric mean $\mathrm{NO}_{3}^{-} / \mathrm{PO}_{4}^{3-}$ ratio $(\sim 24)$ was significantly higher than in the upper $150 \mathrm{~m}(\sim 7)$, where it varied seasonally with low ratios $(3,5)$ during autumn and winter compared to summer and spring $(9,11)$. At the present time, it is not possible to reconcile the relatively low $(<16) \mathrm{NO}_{3}^{-} / \mathrm{PO}_{4}^{3-}$ ratios and apparent $\mathrm{N}$ dependence in the euphotic zone with the high $(>20)$ ratios of exogenous upwelling and atmospheric inputs. The determination of the possible presence of additional nutrient phases and preferential uptake of nutrients by the phytoplankton is an important next step toward the understanding of nutrient limitation in such ultra-oligotrophic systems. (C) 2000 Ifremer/CNRS/IRD/Éditions scientifiques et médicales Elsevier SAS
\end{abstract}

nutrients / Mediterranean / chlorophyll $a$ / oligothropy

Résumé - Dynamique saisonnière des nutriments et de la chlorophylle $a$ sur la marge continentale du SE de la Méditerranée. Ce travail présente les résultats d'une série de douze campagnes (juin 1996 à mai 1998) portant sur les nutriments (nitrates, phosphates et silicates) et la chlorophylle $a$. L'étude a porté sur deux stations permanentes, l'une sur la plate-forme (profondeur $120 \mathrm{~m}$ ), l'autre sur la pente continentale $(400 \mathrm{~m})$ au SE de la Méditerranée. Les variations de la chlorophylle $a$ s'étendent de 0,003 à $0,415 \mathrm{mg} \mathrm{m}^{-3}$. Un pic de chlorophylle apparaît aussi bien en fin d'automne qu'en fin d'hiver ( $\neq 30 \mathrm{mg} \mathrm{Chl} a \mathrm{~m}^{-2}$ dans les 120 premiers mètres) avec un maximum secondaire à la fin du printemps. Dans la zone de décomposition (120 $\mathrm{m}$ à $400 \mathrm{~m})$, les variations de nitrates et de phosphates présentent une allure opposée avec une diminution durant l'hiver. Le modèle intégré de $\mathrm{Si}(\mathrm{OH})_{4}$ dans la couche euphotique souligne la rupture de la stratification verticale. Entre $150 \mathrm{~m}$ et $400 \mathrm{~m}$, la moyenne géométrique du rapport $\mathrm{NO}_{3}^{-} / \mathrm{PO}_{4}^{3-}(\neq 24)$ est nettement plus élevée que dans les cent cinquante premiers mètres $(\neq 7)$ où il varie avec les saisons avec des valeurs basses (respectivement 3 et 5 ) en automne -

\footnotetext{
* Correspondence and reprints.

E-mail address: barak@ocean.org.il (B. Herut).
}

(C) 2000 Ifremer/CNRS/IRD/Éditions scientifiques et médicales Elsevier SAS. Tous droits réservés. 
hiver comparé à l'été et au printemps (respectivement 9 et 11). Actuellement, il est impossible de relier les rapports nitrates/phosphates relativement bas $(<16)$ et l'apparente dépendance du phytoplancton à l'égard de l'azote dans la couche euphotique avec les taux élevés $(>20)$ des apports atmosphériques et de l'upwelling extérieur. L'apport additionnel de nutriments, ainsi que les préférences éventuelles du phytoplancton, constituent la prochaine étape pour la compréhension de la limitation par les nutriments dans les systèmes ultra-oligotrophes. (C) 2000 Ifremer/CNRS/IRD/Éditions scientifiques et médicales Elsevier SAS

\section{nutriments / Méditerranée / chlorophyll $a$ / oligothropie}

\section{INTRODUCTION}

Many studies have found evidence of extremely low nutrient concentrations and of exceptionally oligotrophic conditions in the waters of the central Levantine Basin (Berman et al., 1984, 1985; Dowidar, 1984; Salihoglu et al., 1990; Krom et al., 1991, 1992; Krom et al., 1993; Yacobi et al., 1995). These conditions have also been observed in the coastal waters of the SE Mediterranean (Berman et al., 1986; Azov, 1986; Abdel-Moati, 1990; Gitelson et al., 1996). In both areas, the Chl $a$ concentrations were below $0.9 \mathrm{mg} \mathrm{m}^{-3}$ (Berman et al., 1984; Azov, 1986; Krom et al., 1992, 1993; Yacobi et al., 1995), and a deep Chl $a$ maximum (DCM) develops between 75 and $150 \mathrm{~m}$, typical of oligotrophic waters (Dowidar, 1984; Berman et al., 1984; Kimor et al., 1987; Abdel-Moati, 1990). The DCM has a regular distribution across the basin during the summer and is not significantly affected by physical oceanographic structures (Yacobi et al., 1995). Remote sensing studies using the coastal zone color scanner showed some interannual and seasonal variations, but the different studies reported different patterns, probably as a result of the use of different algorithms to process the data (Antoine et al., 1995; Van Dijken and Arrigo, 1996).

Several studies have used the elemental ratios of dissolved nutrients (N, P and $\mathrm{Si}$ ) in marine environments in order to determine which element might be limiting phytoplankton growth (Codispoti, 1989; Krom et al., 1991; Dortch and Whiteledge, 1992; Fanning, 1992; Justic et al., 1995). In the SE Mediterranean, Krom et al. (1991) found unusually high $(>27) \mathrm{NO}_{3}^{-} / \mathrm{PO}_{4}^{3-}$ ratios, and $\mathrm{PO}_{4}^{3-}$ (as compared to $\mathrm{NO}_{3}^{-}$) was preferentially removed from the upper water column. They suggested that the productivity in that region might be limited by the availability of phosphorus. Nutrient enrichment experiments showed that $\mathrm{P}$ rather than $\mathrm{N}$ was the limiting nutrient for bacterial activity (Thingstad and Rassoulzadegan, 1995; Zohary and Robarts, 1998). The cause of this P-limitation and of the unusually high $\mathrm{NO}_{3}^{-} / \mathrm{PO}_{4}^{3-}$ ratios in the deep eastern Mediterranean are still not known. However, until now, no assessment of nutrient elemental ratios has been done for the pelagic waters across the continental shelf and the slope of the SE Mediterranean.

Krom et al. (1991) hypothesized that this P-limitation was due to the removal of $\mathrm{PO}_{4}^{3-}$ by adsorption on dust particles. Recently, it was estimated that this adsorption process could not explain such phosphate 'deficits' (Herut et al., 1999a) and that the atmospheric inputs of $\mathrm{N}$ and $\mathrm{P}$ to this region reinforce the unusual $\mathrm{NO}_{3}^{-} / \mathrm{PO}_{4}^{3-}$ ratios (Herut et al., 1999b). Other theories suggested were nitrogen fixation (Bethoux et al., 1998) and $\mathrm{NO}_{3}^{-}$enriched waters of Adriatic origin forming the deep eastern Mediterranean waters (Civitarese et al., 1998).

Although the water chemistry of the SE Mediterranean sea has undoubtedly changed since the construction of the high Aswan dam in 1965 and the consequent drastic decrease in nutrients supplied by the Nile outflow (Milliman, 1991), the data which might document these long-term changes in the neritic and pelagic zones of this region are scarce. Prior to construction of the dam, the Nile floods peaked between August and October (Sharaf El Din, 1977) and triggered a major phytoplankton bloom off the Egyptian coast (Dowidar, 1984). A coincident phytoplankton bloom was also observed in the nearshore waters along the coast of Israel and Lebanon (Oren and Komarovsky, 1961). According to Schneller et al. (1984), Berman et al. (1986) and Azov (1986), since 1965 the seasonality of the phytoplankton blooms have changed to the winter-spring period. However, the existing data do not permit a detailed analysis of seasonal or time series changes of the nutrient and Chl $a$ concentrations. 
In order to address some of these problems, we developed a study to examine in detail the seasonal vertical distributions of nutrients and $\mathrm{Chl} a$, as well as the physical properties of the water column, at two permanent stations off the Israeli coast (SE Mediterranean). A map with the sampling localities is shown in figure 1. The stations were visited bi-monthly during two consecutive years, from June 1996 to May 1998. The goals were: (1) to determine the seasonal variations of the nutrient and Chl $a$ profiles in the water column; (2) to examine the relationships between the nutrient and the Chl $a$ concentrations; and (3) to examine the seasonal variations in the ratio of $\mathrm{NO}_{3}^{-} / \mathrm{PO}_{4}^{3-}$.

\subsection{Hydrographic background}

The extreme nutrient-depletion of the eastern Mediterranean is apparently caused by the general W-E anti-estuarine circulation, which transports the deepwater nutrients from the Mediterranean into the north Atlantic (Bethoux et al., 1998). The circulation patterns and water mass characteristics of the eastern Mediter- ranean have been studied as part of the research initiative, 'Physical Oceanography of the eastern Mediterranean' (POEM Group, 1992; Ozsoy et al., 1993). Based upon the variations of salinity with depth in the water column, Hecht et al. (1988) identified four different water masses in the SE Levantine waters. These are: the Levantine surface water, Atlantic water, Levantine intermediate water, and deep water.

The two upper water masses show seasonal variations in their properties. The upper $100 \mathrm{~m}$ of the water column is well mixed during winter, but it is stratified during the remainder of the year, with a mixed layer restricted to the upper $25 \mathrm{~m}$ and a sharp halocline and thermocline below the mixed layer.

The circulation on the Israeli shelf is dominated by geostrophic currents, which are mainly northward, and by shelf waves (Rosentraub, 1995). Fluctuations in the currents occur on both diurnal (from variations in sea breezes) and synoptic (3-14 days) timescales. The strongest currents are predominately northward and occur in winter and summer. In spring and autumn, the currents are weaker and alternate from north to south

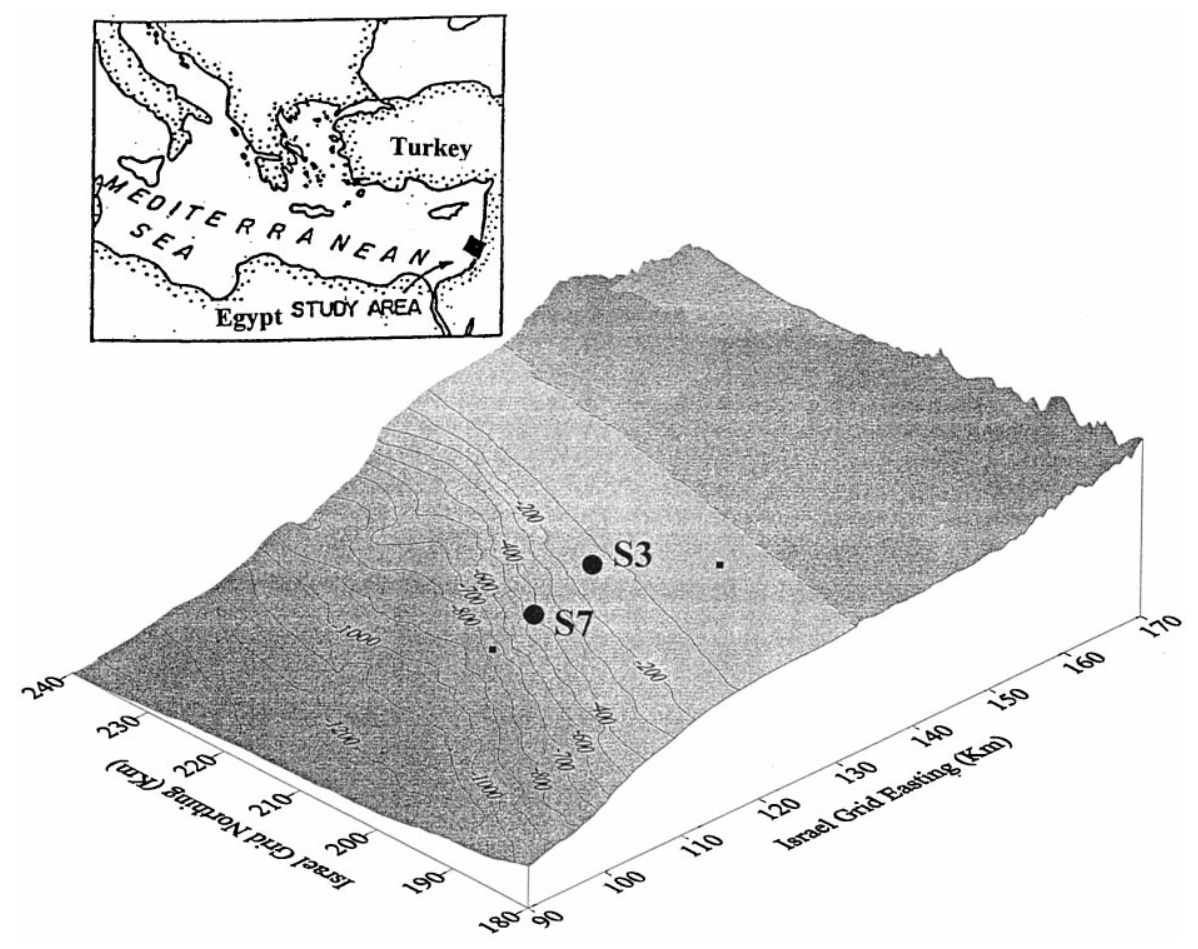

Figure 1. Map of the Mediterranean sea and the location of the two sampling stations. Station S3 is located over the continental shelf where the water depth is $120 \mathrm{~m}\left(32^{\circ} 26.55^{\prime} \mathrm{N} ; 34^{\circ} 42.85^{\circ} \mathrm{E}\right)$. Station $\mathrm{S} 7$ is located on the continental slope, where the water depth is $400 \mathrm{~m}$ $\left(32^{\circ} 27.65^{\prime} \mathrm{N} ; 34^{\circ} 39.35^{\prime} \mathrm{E}\right)$. 
Table I. Cruise dates arranged by the season of the year. ${ }^{\text {a }}$

\begin{tabular}{lllll}
\hline Summer & $25 / 06 / 96$ & $28 / 08 / 96$ & $24 / 06 / 97$ & $03 / 09 / 97$ \\
Fall & $17 / 10 / 96$ & $02 / 11 / 97$ & & \\
Winter & $24 / 12 / 96$ & $05 / 02 / 97$ & $14 / 01 / 98$ & $02 / 03 / 98$ \\
Spring & $06 / 05 / 97$ & $17 / 05 / 98$ & & \\
\hline
\end{tabular}

${ }^{\text {a }}$ Dates given as DD/MM/YY.

(Rosentraub, 1995). During the summer period, the relatively strong and fluctuating currents, confined to the upper layer, increase in intensity towards the continental slope to mean speeds of $40 \mathrm{~cm} \mathrm{~s}^{-1}$. In the winter period when there is mixing, the distribution of the currents is uniform throughout the water column.

\section{SAMPLING AND METHODS}

The fieldwork for this study was conducted during twelve cruises on the R/V Shikmona, under the auspices of the Dutch-Israeli LEV project. The cruises took place bi-monthly, and each one visited the two permanent sampling stations which had been established for the project (figure 1). The water depths, latitudes and longitudes for these stations are given in the caption of figure 1. The dates of the cruises and their seasonal category are given in table $I$.

During each visit to each of the stations, water samples were collected with twelve $1.7 \mathrm{~L}$ Niskin bottles mounted on a General Oceanics Rosette. At the same time, a Sea-Bird SBE $9+$ electronic CTD was used to obtain continuous vertical profiles of temperature $(T)$, salinity $(S)$ and oxygen. The bottles were closed at depths determined from the temperature and salinity profiles.

Immediately after the rosette was hauled aboard, sample aliquots were taken from each Niskin bottle for analyses of dissolved oxygen, nutrients $\left(\mathrm{NO}_{3}^{-}+\mathrm{NO}_{2}^{-}\right.$, $\mathrm{PO}_{4}^{3-}$ and $\mathrm{Si}(\mathrm{OH})_{4}$ ), and $\mathrm{Chl} a$. The dissolved oxygen aliquots were pickled. The nutrient aliquots were divided into triplicate samples and stored in $15 \mathrm{~mL}$ plastic scintillation vials that had been prewashed with $10 \%$ hydrochloric acid and rinsed three times with the sample prior to being filled. The nutrient samples were then immediately frozen $\left(-18{ }^{\circ} \mathrm{C}\right)$.

For Chl $a$ analyses a $400 \mathrm{~mL}$ aliquot from each Niskin bottle was pre-filtered through a $63 \mu \mathrm{m}$ sieve and then filtered using glass fiber filters $(\mathrm{GF} / \mathrm{F})$. The filters were folded and packed in $\mathrm{Al}$ foil and immediately frozen $\left(-18^{\circ} \mathrm{C}\right)$.

In addition to the continuous CTD oxygen profile obtained on-station, during the last seven cruises, oxygen measurements were carried out using the Carpenter-Winkler titration procedure (Carpenter, 1965) and a Radiometer automatic titrator (TTT80) equipped with a dead-stop end point dual platinum electrode. The precision for these measurements was $0.4 \%$. The two methods of measurement gave similar results $( \pm 2 \%)$, except for two cruises $(06 / 05 / 97$ and 24/06/97) in which we used the titration values to correct the CTD data (by approximately $10 \%$ ).

The amount of Chl $a$ in each filtered sample was determined using acetone extraction and fluorometric measurements following the procedure developed by Holm-Hansen et al. (1965). The fluorometer has a detection limit of $0.1 \mu \mathrm{g} \mathrm{L}^{-1}$ that corresponds to a seawater concentration of $1.2 \mathrm{ng} \mathrm{Chl} a \mathrm{~L}^{-1}$. Nutrient concentrations were determined in the laboratory using a segmented-flow, Technicon autoanalyser II (AAII) system following the methods described by Krom et al. (1992; 1993). The limit of detection for these procedures was defined as equal to 2 times the standard deviation of the blank. Our values for the detection limits were $0.05 \mu \mathrm{M}$ for $\mathrm{NO}_{3}^{-}+\mathrm{NO}_{2}^{-}, 0.008 \mu \mathrm{M}$ for $\mathrm{PO}_{4}^{3-}$, and $0.3 \mu \mathrm{M}$ for $\mathrm{Si}(\mathrm{OH})_{4}$. The analytical precision for $\mathrm{NO}_{3}^{-}+\mathrm{NO}_{2}^{-}, \mathrm{PO}_{4}^{3-}$ and $\mathrm{Si}(\mathrm{OH})_{4}$ was $0.02 \mu \mathrm{M}$, $0.003 \mu \mathrm{M}$, and $0.06 \mu \mathrm{M}$, respectively. In this paper, we refer to $\mathrm{NO}_{3}^{-}+\mathrm{NO}_{2}^{-}$as $\mathrm{NO}_{3}^{-}$.

\section{RESULTS}

\subsection{Physical structure of the water column}

Because of its water depth (400 m), station S7 usually contained the complete range of the different water masses found of the Levantine Basin including the Levantine surface water (LSW), the Atlantic water (AW), the Levantine intermediate water (LIW), and the uppermost zone of the deep water (DW). As discussed by Hecht et al. (1988) and obtained here, each of these water masses is defined by a typical $\mathrm{T}-\mathrm{S}$ shape diagram. The seasonal $\mathrm{T}$ and $\mathrm{S}$ depth profiles (at both stations) indicate that both the vertical and the lateral distribution of the three upper water masses change seasonally and annually (figure 2). 
At both stations $\mathrm{S} 3$ and $\mathrm{S} 7$, the mixed surface layer is approximately $20 \mathrm{~m}$ thick in summer, with a minimum thickness of $\sim 13 \mathrm{~m}$. In winter, it reaches a maximum depth of $\sim 150 \mathrm{~m}$ (figure 2). The seasonal thermocline is usually located between 20 and $80 \mathrm{~m}$, below the top of the mixed layer and above the weak permanent thermocline. During autumn and winter, cooling and strong winds cause gradual convective mixing and progressively erode and deepen the seasonal thermocline and halocline until they disappear during the height of the winter (figure 2). The seasonal $\mathrm{T}-\mathrm{S}$ variations have a characteristic pattern, with a wider range of temperatures and salinity during summer and autumn than during the winter and spring. Because of increased evaporation in the summer, the AW is overlain by the saltier and warmer LSW. In the winter, AW cannot be distinguished from LSW, which progressively thins as winter proceeds.

During winter, the dissolved oxygen concentration profile was constant in the upper $\sim 150 \mathrm{~m}$ of the water column, and between 150 and $400 \mathrm{~m}$, decreased to a constant value $\left(\sim 6 \mathrm{mg} \mathrm{L}^{-1}\right)$. This decrease is charac-
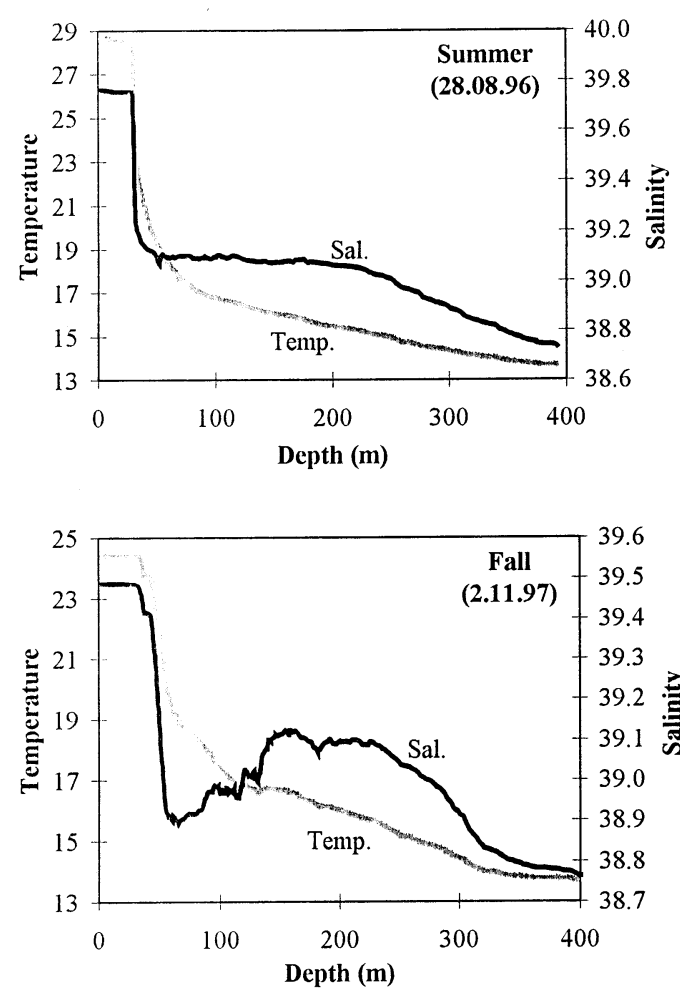

terized by three consecutive, gradual declines, between $\sim 150$ and $180 \mathrm{~m}$, between 180 and $270 \mathrm{~m}$, and between 270 and $330 \mathrm{~m}$. In spring, a small maximum of dissolved oxygen $\left(\sim 7.4 \mathrm{mg} \mathrm{L}^{-1}\right)$ was detected between 30 and $80 \mathrm{~m}$. During summer, it increased to a maximum value of $\sim 8 \mathrm{mg} \mathrm{L}^{-1}$ at $\sim 80 \mathrm{~m}$ water depth. Also in summer, the gradient beneath the oxygen maximum at $\sim 80 \mathrm{~m}$ is steeper down to $\sim 150 \mathrm{~m}$ depth. In autumn, the well-established oxygen maximum starts to erode and has a shallower gradient between 150 and $400 \mathrm{~m}$, similar to that observed during other seasons. In general, the oxygen profile was opposite to the nutrient profile (discussed below). During the winter and spring, the highest dissolved oxygen concentrations were observed in the LSW and AW masses.

\subsection{Nutrients}

Our results show that the dissolved nutrient concentrations $\left(\mathrm{PO}_{4}^{3-}, \mathrm{NO}_{3}^{-}\right.$and $\left.\mathrm{Si}(\mathrm{OH})_{4}\right)$ have a characteristic vertical profile, with low values in the upper water
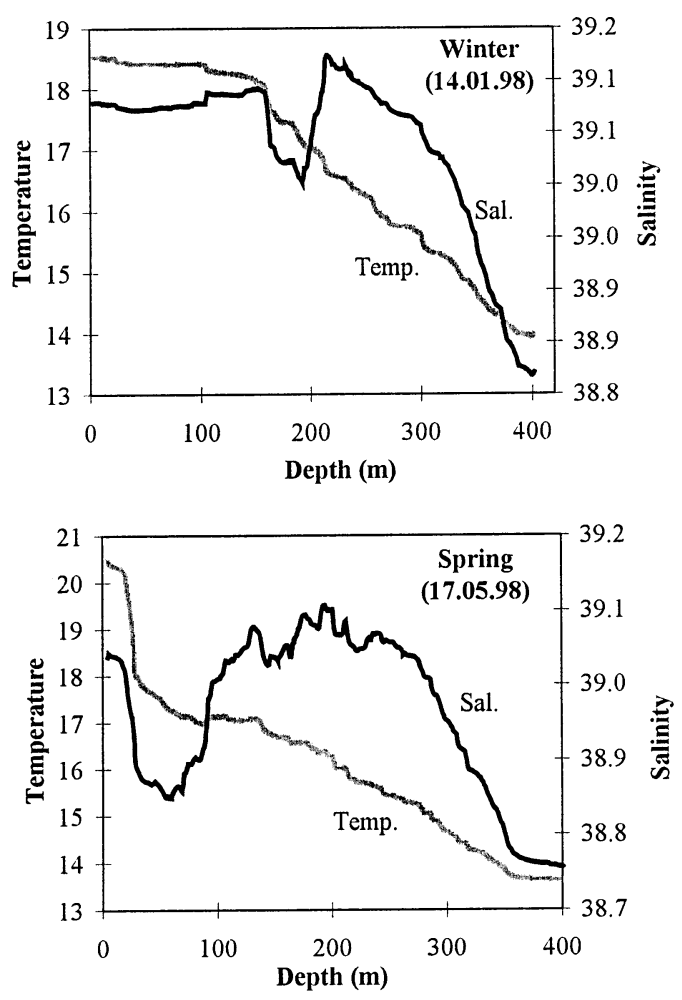

Figure 2. Representative seasonal vertical profiles of temperature $\left({ }^{\circ} \mathrm{C}\right)$ and salinity at stations $\mathrm{S} 7$. 

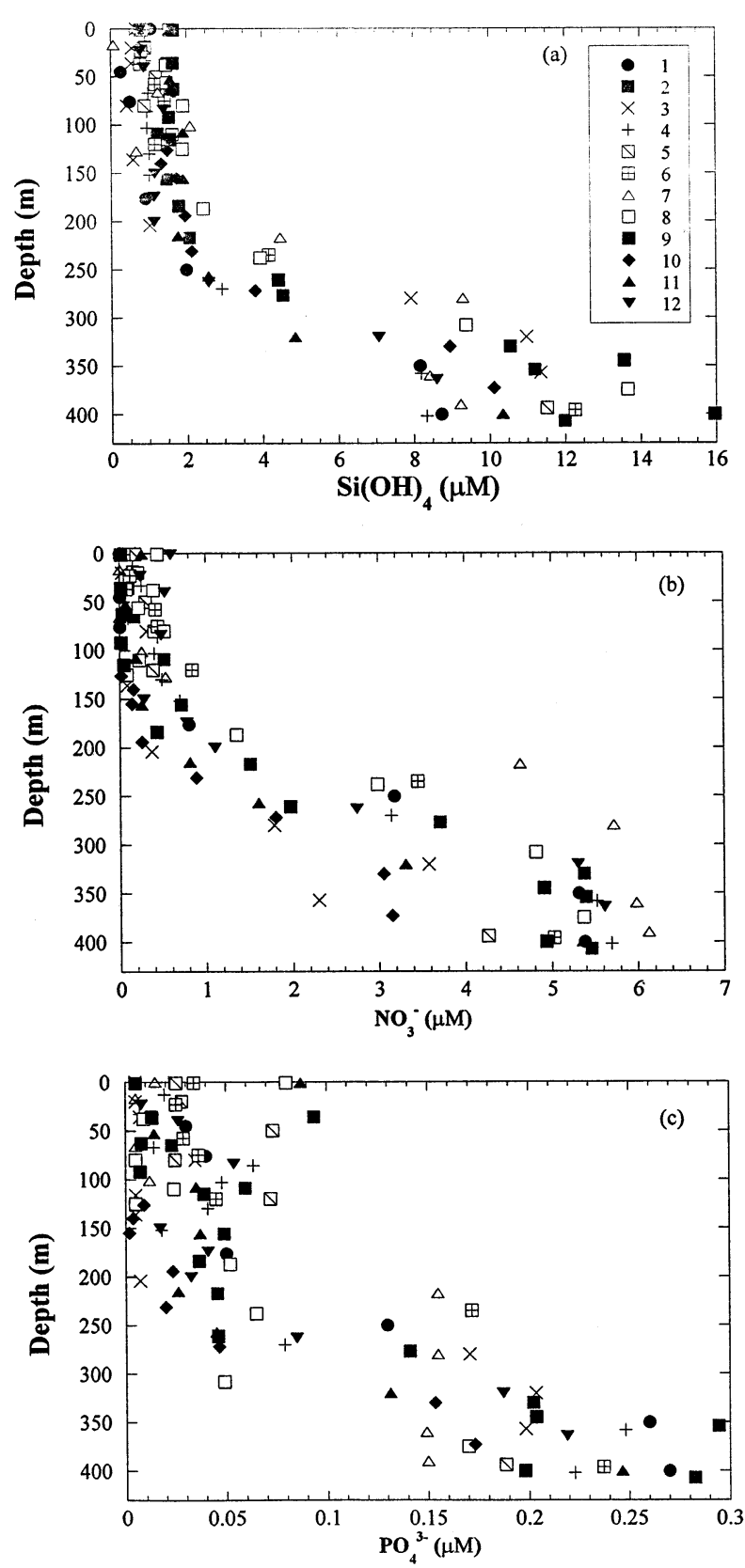

Figure 3. Vertical profiles of (a) $\mathrm{Si}(\mathrm{OH})_{4}$, (b) $\mathrm{NO}_{3}^{-}$and (c) $\mathrm{PO}_{4}^{3-}$ concentrations $(\mu \mathrm{M})$ at station $\mathrm{S} 7$ during 12 consecutive cruises: cruises 1 and 2 took place during autumn (17/10/96 and 02/11/97); cruises 3 and 4 during spring (06/05/97 and 17/05/98); cruises 5 through 8 during summer $(25 / 06 / 96,28 / 08 / 96,24 / 06 / 97$, and 03/09/ 97); and cruises 9 through 12 occurred during winter (24/12/96, $05 / 02 / 97,14 / 01 / 98$ and $02 / 03 / 98)$.

column between 0 and roughly $150-200 \mathrm{~m}$ depth. It varies from below the detection limit to somewhat higher nutrient values of $0.09,0.9$ and $2.5 \mu \mathrm{M}$, respectively (figure 3). The nutricline becomes evident at $150-200 \mathrm{~m}$ depth, and nutrient concentrations increase to maximal values of $0.29,6.12$ and $16.0 \mu \mathrm{M}$, respectively, at about $400 \mathrm{~m}$ water depth (figure 3). The nutricline shifts to shallower depths in summer $(\sim 150 \mathrm{~m})$ than in winter and autumn $(\sim 200 \mathrm{~m})$, with generally higher concentrations in the decomposition zone (120-400 $\mathrm{m})$ during summer.

The depth-integrated concentrations of $\mathrm{Si}(\mathrm{OH})_{4}$, $\mathrm{PO}_{4}^{3-}$ and $\mathrm{NO}_{3}^{-}$in the upper $120 \mathrm{~m}$ layer (i.e., the euphotic zone; (Parsons et al., 1977)) varied from low values near the detection limits up to maximum concentrations of 220,5 and $50 \mathrm{mmol} \mathrm{m}^{-2}$, respectively (figure 4). Generally, the data from station S3 and the data from the more scattered sampling intervals in the upper $120 \mathrm{~m}$ of station $\mathrm{S} 7$ show a similar pattern. The depth-integrated concentration of $\mathrm{Si}(\mathrm{OH})_{4}$ in the upper $120 \mathrm{~m}$ layer was higher during winter and autumn and lower during spring. We also detected quite low concentrations during the summer and autumn, except during September 1997.

The $\mathrm{PO}_{4}^{3-}$ concentration of the euphotic zone showed no specific seasonal behavior in the first year, and during the second year, it reached maximum values in autumn and winter. The $\mathrm{NO}_{3}^{-}$concentrations were lowest from late autumn through early winter and highest during the spring and summer. In general, the neritic (S3) and pelagic (S7) waters had similar seasonal variations in their $\mathrm{NO}_{3}^{-}$and $\mathrm{Si}(\mathrm{OH})_{4}$ concentrations and differences in their seasonal concentrations of $\mathrm{PO}_{4}^{3-}$.

Nutrient concentrations in the decomposition zone between 120 and $400 \mathrm{~m}$ were low during winter, after the convective mixing period. The nutrient concentration increased from the end of the winter until the end of the summer (figure 5). The $\mathrm{PO}_{4}^{3-}$ had an additional decline in September 1997. The integrated concentrations of $\mathrm{NO}_{3}^{-}$and $\mathrm{PO}_{4}^{3-}$ in the $200-400 \mathrm{~m}$ interval were similar to those of the $120-400 \mathrm{~m}$ interval. Both nutrient species had similar absolute values during winter, but the stratification of the water column during the other seasons probably enhanced the decomposition of 'trapped' organic matter in the upper $120-200 \mathrm{~m}$, and this is reflected by the higher nutrient integrated values (figure 5). 


\subsection{Chlorophyll $a$}

Chl $a$ concentrations vary seasonally, and they range between 0.003 and $0.415 \mathrm{mg} \mathrm{m}^{-3}$, similar to $\mathrm{Chl} a$ concentrations in other areas of the Levantine Basin (Berman et al., 1986; Yacobi et al., 1995; Gitelson et al., 1996). We found the most pronounced seasonal differences in the surface water (figure 6), where Chl $a$ concentrations were $2-5$ times higher during autumn and winter (mean values of 0.13 and $0.14 \mathrm{mg} \mathrm{m}^{-3}$ ) compared to summer and spring (mean values of 0.03 and $0.04 \mathrm{mg} \mathrm{m}^{-3}$ ). The Chl $a$ vertical profile and the depth of the DCM vary seasonally at both stations. During autumn and winter, Chl $a$ was more evenly
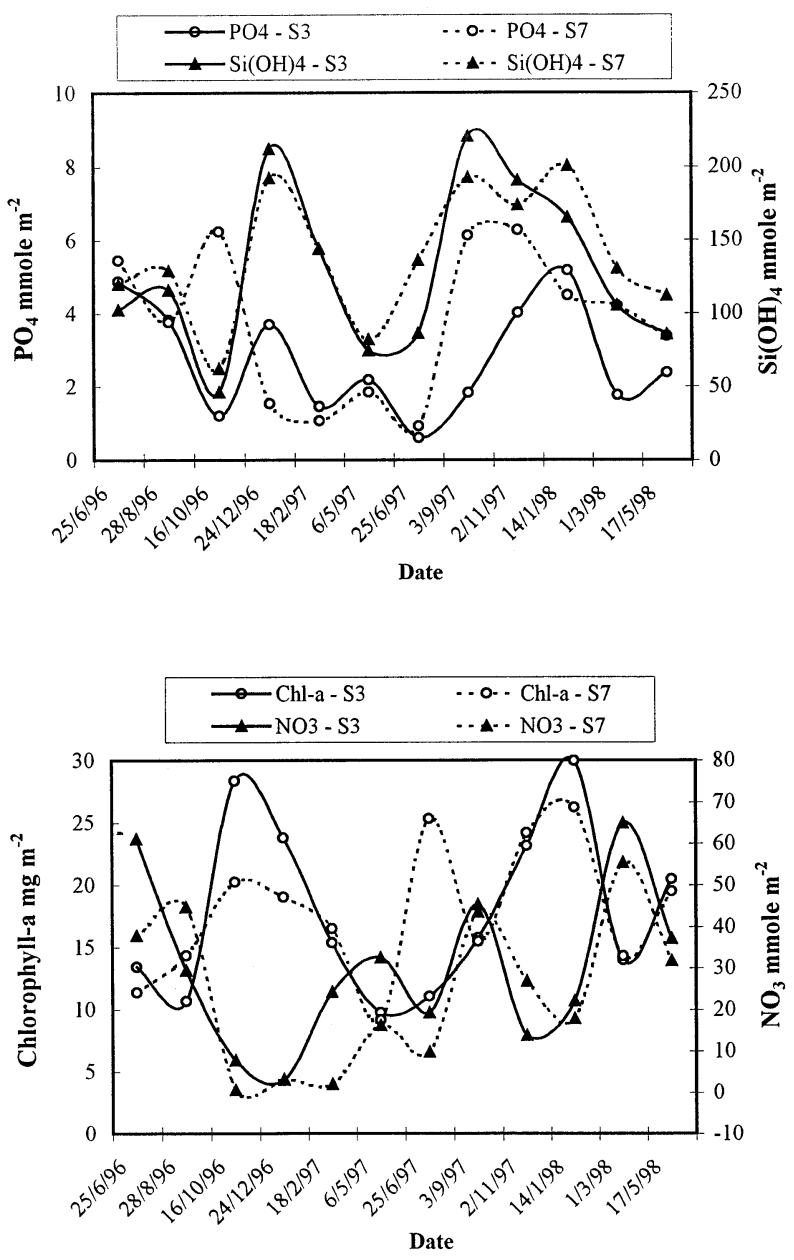

Figure 4. The depth-integrated concentrations (0-120 m, euphotic zone) of $\mathrm{Si}(\mathrm{OH})_{4}, \mathrm{NO}_{3}^{-}, \mathrm{PO}_{4}^{3-}$ and $\mathrm{Chl} a$ over two annual cycles at stations $\mathrm{S} 3$ and $\mathrm{S} 7$.

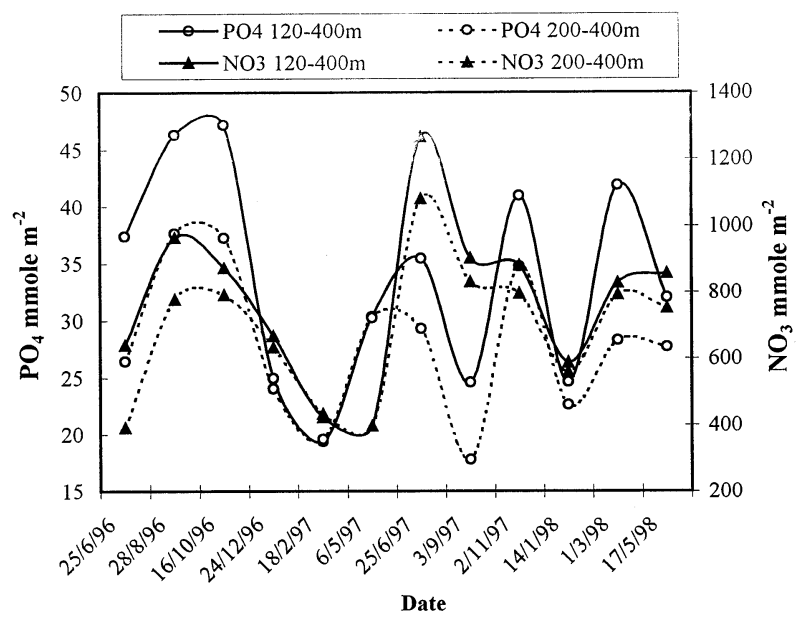

Figure 5. The depth-integrated concentrations (at 120-400 or 200-400 m, decomposition zone) of $\mathrm{NO}_{3}^{-}$and $\mathrm{PO}_{4}^{3-}$ over two annual cycles at stations $\mathrm{S} 7$.

distributed in the upper $\sim 150 \mathrm{~m}$ of the water column (figure 6). During spring and summer, a DCM was established and it was most pronounced between $100-120 \mathrm{~m}$ water depth. During the fall, the DCM shifted upwards to water depths of approximately $80 \mathrm{~m}$.

As shown in figure 4, the depth-integrated values of Chl $a$ ranged between 10 and $30 \mathrm{mg} \mathrm{m}^{-2}$ in the upper $120 \mathrm{~m}$ and between 20 and $38 \mathrm{mg} \mathrm{m}^{-2}$ in the upper $200 \mathrm{~m}$. These values are similar to those for the upper $200 \mathrm{~m}$ of the Levantine Basin (Yacobi et al., 1995). The integrated $\mathrm{Chl} a$ content in the euphotic zone (upper $120 \mathrm{~m}$ ) was seasonally dependent, with autumn and winter values higher by approximately a factor of 3 compared to summer values. Additional $\mathrm{Chl} a$ peak was detected during spring 1997 and 1998 at station S7 (figure 4).

\section{DISCUSSION}

During autumn and winter, the water column in this region cools down and becomes mixed to a water depth of about $150 \mathrm{~m}$ (figure 2). This is thought to cause a significant input of nutrients into the euphotic zone from the water layers below. These nutrients are quickly consumed and produce a phytoplankton peak during winter time. A similar seasonality has been observed in the boundary zone of the Cyprus Eddy in 
the eastern Mediterranean (Krom et al., 1992, 1993). There, increases in biomass during the winter (February) caused a phytoplankton bloom of $44 \mathrm{mg} \mathrm{Chl} a \mathrm{~m}^{-2}$, while in summer the concentration decreased to $10-13 \mathrm{mg} \mathrm{Chl} a \mathrm{~m}^{-2}$. Our data show that the annual cycles of $\mathrm{NO}_{3}^{-}$and $\mathrm{PO}_{4}^{3-}$ in the decomposition zone $(120-400 \mathrm{~m})$ were opposite to the cyclicity in the overlying water. The lowest concentration of nutrients was observed during winter and coincided with a Chl $a$ maximum in the upper water column (figure 4). A moderate Chl $a$ peak (upper $120 \mathrm{~m}$ ) was observed at both stations during spring of 1998. During 1997, we observed a similar increase in Chl $a$ only in the offshore station (S7). This may be related to local in-offshore variability.
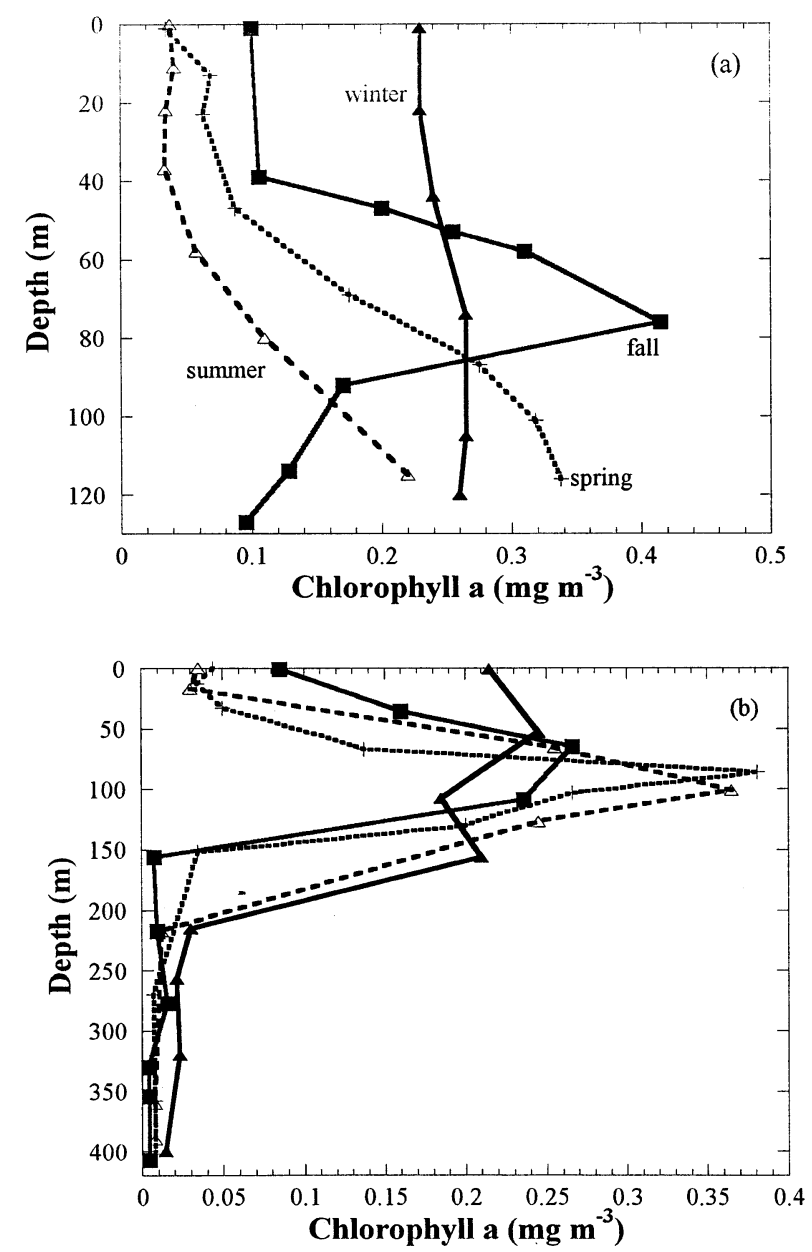

Figure 6. Representative seasonal vertical profiles of $\mathrm{Chl} a$ concentrations at stations (a) S3 and (b) S7.
In the euphotic zone, the integrated $\mathrm{NO}_{3}^{-}$values are generally opposite to those of the $\mathrm{Chl} a$, and both are unrelated to the variability of $\mathrm{PO}_{4}^{3-}$ and $\mathrm{Si}(\mathrm{OH})_{4}$ (figure 4). The concentrations of $\mathrm{PO}_{4}^{3-}$ vary interannually, but with no specific seasonal pattern in the first year. In the second year, it was low in late winter-spring and high during fall-early winter. This $\mathrm{PO}_{4}^{3-}$ behavior is not clear and might reflect a possible transfer or storage of dissolved $\mathrm{P}$ between/within different phases that were not measured in this study (i.e., dissolved organic P, adsorbed $\mathrm{P}$, particulate $\mathrm{P}$ ).

The $\mathrm{Si}(\mathrm{OH})_{4}$ annual variability might reflect possible diatom blooms during periods of low silica concentrations and the settling of diatom frustules before periods of high silica peaks (figure 4). Some diatom species in the eastern Mediterranean (Kimor et al., 1987; Ignatiades et al., 1995) show a distinct adaptation to stratified oligotrophic waters (Abdel-Moati, 1990; Villareal, 1991; Goldman, 1993). The rapid silicate buildup in the euphotic zone (see slopes in figure 4) may represent a period of massive diatom sinking within the annual cycle. This generally occurs in the fall-winter (Sancetta et al., 1991). Thus, during spring and summer when the water column is stratified, diatom growth might occur, while during the breakdown of stratification by the winter mixing, the diatom growth falters and they settle down. High $\mathrm{Si}(\mathrm{OH})_{4}$ concentrations were observed in September 1997 (figure 4), indicating a possible earlier diatom deposition event that may be related to unusual high salinity and temperature values and their depth profiles (figure 2 ). Both profiles suggest some breakdown of stratification. Thus, the moderate peaks of $\mathrm{Chl} a$ during spring probably are related to the diatoms bloom.

To assess the export flux of diatoms (or associated organic carbon), we assumed that the increase of $\mathrm{Si}(\mathrm{OH})_{4}$ between the spring/summer periods and the autumn when the highest values occur represent the mass of precipitated diatoms. Using a biogenic $\mathrm{Si} / \mathrm{C}$ ratio of $0.36 \pm 0.1$ in DCM of the SE Mediterranean (Abdel-Moati, 1990), which exceeds the typical diatom ratio of 0.14 (Brezezinsky, 1985), and assuming that the integrated $\mathrm{Si}(\mathrm{OH})_{4}$ increase of $\sim 130 \mathrm{mmol} \mathrm{Si} \mathrm{m}^{-2}$ (figure 4) represents the annual event of fast deposition, this mass is roughly $\sim 4.3 \mathrm{~g} \mathrm{C} \mathrm{m}^{-2} \mathrm{yr}^{-1}$. Kemp et al. (1999) suggested that such rapid, massive annual deposition of diatoms is the main mechanism for the formation of Mediterranean sapropels in the late 
Quaternary. Assuming that the sum of the Chl $a$ integrated values over an annual cycle represents the total phytoplankton load, the first (June 1996-June 1997) and second (May 1997-May 1998) years of our study had similar Chl $a$ values of 112 and $124 \mathrm{mg} \mathrm{Chl}$ $a \mathrm{~m}^{-2} \mathrm{yr}^{-1}$ in the upper $120 \mathrm{~m}$ (station S3 and S7), and 186 and $216 \mathrm{mg}$ Chl $a \mathrm{~m}^{-2} \mathrm{yr}^{-1}$ in the upper $200 \mathrm{~m}$ (station S7). This load in the upper $200 \mathrm{~m}(\sim 200 \mathrm{mg}$ Chl $\left.a \mathrm{~m}^{-2} \mathrm{yr}^{-1}\right)$ is equivalent to approximately $41-49 \mathrm{~g}$ $\mathrm{C} \mathrm{m}^{-2} \mathrm{yr}^{-1}$, using C: Chl $a=206-245$ (by weight; Abdel-Moati, 1990).

The depth range of DCM between 80 and $120 \mathrm{~m}$ found in the present study is similar to the depth range found in previous studies in the SE Mediterranean (Berman et al., 1986; Abdel-Moati, 1990; Salihoglu et al., 1990; Krom et al., 1992; Yacobi et al., 1995) as well as in other oligotrophic regions (Cullen, 1982). The light penetration at these depths is $1 \%$ or less of the surface incident radiation (Abdel-Moati, 1990; Berman et al., 1986), in accordance with 32 and $41 \mathrm{~m}$ secchi disk depths (measured in August 1996 and May 1998 at station S3 and S7, respectively) and similar to light intensities found in other oligotrophic areas. At station S7 the DCM was more developed during the summer and spring seasons $\left(\sim 0.3 \mathrm{mg} \mathrm{m}^{-3}\right)$, probably because of the physical structure of the water column and the consequent supply of nutrients to the euphotic zone (and the limit of light penetration). The DCM was always shallower than the main nutricline (between 150 and $200 \mathrm{~m}$ ), similar to previous observations in the eastern Mediterranean (Yacobi et al., 1995).

Several possible sources may contribute nutrients to the euphotic zone. These may include the lower water masses as a result of winter mixing, transport across the nutricline by eddy diffusion, horizontal advection, input of terrigenous material, and atmospheric deposition (Eppley, 1989). In oceanic areas with almost no riverine inputs, similar to our study area, the continental shelf sediments are probably an important source of iron and other macronutrients (Johnson et al., 1999). Over the shelf (st. S3), the $\mathrm{PO}_{4}^{3-}, \mathrm{NO}_{3}^{-}$and $\mathrm{NH}_{4}^{+}$ concentrations in the interstitial waters of the upper sediment layers $(0.5 \mathrm{~cm})$ are higher by more than one order of magnitude than in the bottom water $(0.7-1.2$, 13.5-23.7, and 8.3-32 $\mu \mathrm{M}$, respectively; Herut, unpublished data) exporting nutrients to the water column. Combining the relative deep light penetration and the supply of nutrients from the sediment below, probably impose the bottom $(\sim 120 \mathrm{~m})$ DCM location and benthic production. In addition, especially during winter, sediment resuspension due to mixing and lateral advection of nutrients from the Nile delta by the northeasterly currents (Rosentraub, 1995) probably contributes significantly to the nutrient inputs. Over the continental slope (station S7) the winter vertical distribution of Chl $a$ is mainly caused by the deep mixing and eddy diffusion across the nutricline, while the sharp summer peak may reflect a dominant in-situ supply of nutrients derived from the decomposition of 'trapped' phytoplankton on distinct isopycnile layer. Indeed, the DCM was located at higher sigma-t values during summer (28.5-28.9) compared to the winter (28.0-28.6). As previously suggested (Yacobi et al., 1995), a slight gradient may exist between the DCM and the main nutricline as a possible additional source of nutrients. The shift of the nutricline upward during the summer might strengthen this process. However, due to the relatively large scatter of nutrient concentrations in the upper $200 \mathrm{~m}$, it is not clear at what specific depth the nutricline becomes evident (figure 3). A possible additional source may be atmospheric dry precipitates, especially from Saharan dust storms, which occur predominantly during autumn and spring (Herut et al., 1999a).

It has been suggested that ratios of dissolved $\mathrm{NO}_{3}^{-} /$ $\mathrm{PO}_{4}^{3-}>20-30$ indicate that $\mathrm{P}$ is stoichiometrically limited, that $\mathrm{NO}_{3}^{-} / \mathrm{PO}_{4}^{3-}<10$ and $\mathrm{Si}(\mathrm{OH})_{4} / \mathrm{NO}_{3}^{-}>1$ indicate N-limitation, and $\mathrm{Si}(\mathrm{OH})_{4} / \mathrm{NO}_{3}^{-}<1$ and $\mathrm{Si}(\mathrm{OH})_{4} / \mathrm{PO}_{4}^{3-}<3$ show Si-limitation (Dortch and Whiteledge, 1992; Justic et al., 1995). The above criteria are based principally on a phytoplankton nutrient uptake in Redfield ratios, as is observed in most oceanic areas. Limiting criteria may deviate with different nutrient uptake dynamics of a site-specific biota. According to the above criteria, no Si-limitation was detected in this study. The scattergram of $\mathrm{NO}_{3}^{-}$ versus $\mathrm{PO}_{4}^{3-}$ for all the samples showed a linear positive correlation $(r=0.91)$ with a slope of 22.5 and an intercept of -0.16 (figure 7). A similar best-fit was calculated for samples with $\mathrm{NO}_{3}^{-}$and $\mathrm{PO}_{4}^{3-}$ concentrations $>0.01 \mu \mathrm{M}$ (on 142 of 187 samples). The correlation found here was similar to the pattern calculated across the Levantine basin with a slope of 22.9 (Krom et al., 1991). In the latter, the surface depleted zone and the deepest samples $\left(\mathrm{PO}_{4}^{3-}>0.22 \mu \mathrm{M}\right)$ were not included in the calculation. 


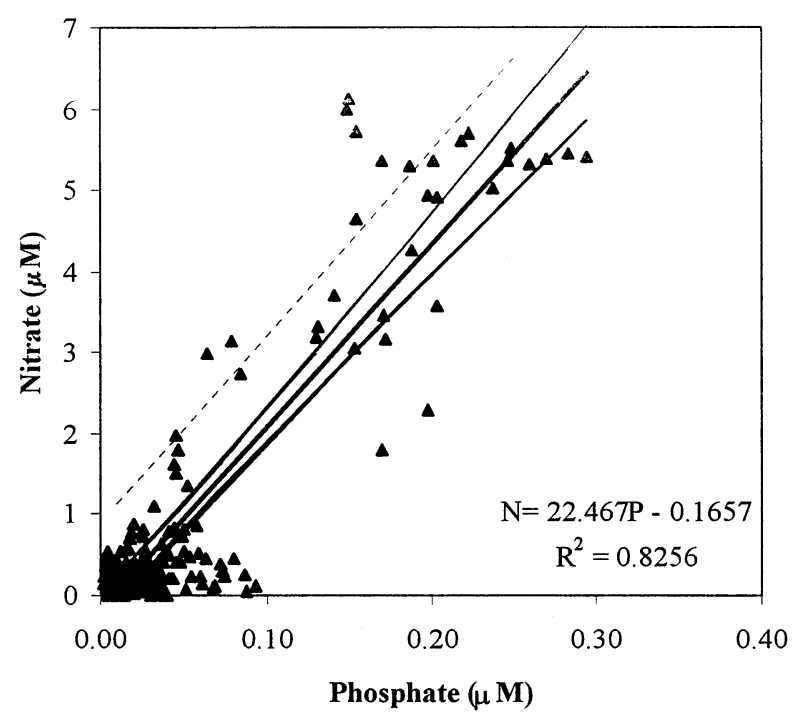

Figure 7. $\mathrm{NO}_{3}^{-}$vs. $\mathrm{PO}_{4}^{3-}$ molar ratios of samples from all cruises. The linear regression curve and the $99 \%$ confidence bands for all the samples are included. The dotted line is the regression line calculated for the SE Levantine basin $(200-2000 \mathrm{~m})$ by Krom et al. (1991).

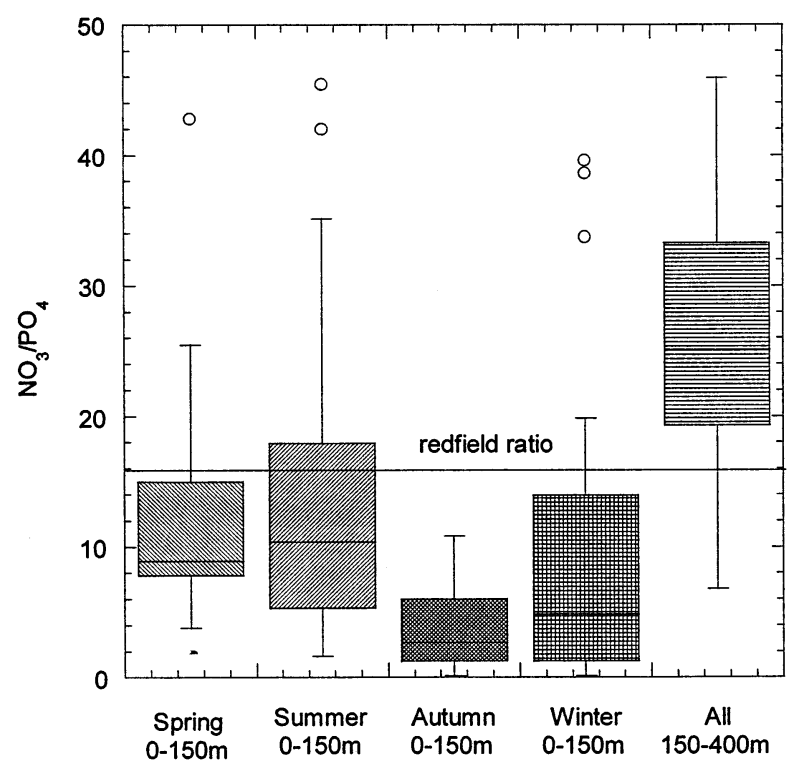

Figure 8. Box plots of the $\mathrm{NO}_{3}^{-} / \mathrm{PO}_{4}^{3-}$ molar ratios in the upper $150 \mathrm{~m}$ for different seasons and in the $150-400 \mathrm{~m}$ depth interval for all samples. The bottom and the top edge of each box are located at the sample 25 and 75 percentiles. The central horizontal line is drawn at the sample median.
In the euphotic zone, the $\mathrm{NO}_{3}^{-} / \mathrm{PO}_{4}^{3-}$ ratios we measured probably have a large error as a result of the low concentrations that were close to the analytical precision of both $\mathrm{PO}_{4}^{3-}$ and $\mathrm{NO}_{3}^{-}$. The expected width of the $\mathrm{NO}_{3}^{-} / \mathrm{PO}_{4}^{3-}$ cluster for our data should be 4 times ( \pm 2 standard deviation) the product of $\mathrm{NO}_{3}^{-} / \mathrm{PO}_{4}^{3-}$ ratio multiplied by its coefficient of variation (C.V.) (Fanning, 1992). For our data the width is centered on a $\mathrm{NO}_{3}^{-} / \mathrm{PO}_{4}^{3-}$ ratio of 22 and increases intensely and symmetrically in the euphotic zone having the extreme low $\mathrm{NO}_{3}^{-}$and $\mathrm{PO}_{4}^{3-}$ concentrations. The actual $\mathrm{NO}_{3}^{-} /$ $\mathrm{PO}_{4}^{3-}$ distribution in the euphotic zone have a different asymmetry shape with significant lower ratios (figure 8 ). Excluding samples with concentrations $<0.01 \mu \mathrm{M}$ (45 samples), the $\mathrm{NO}_{3}^{-} / \mathrm{PO}_{4}^{3-}$ ratios scatter between 1 to 50 in the upper $150 \mathrm{~m}$, but most of the samples $(80 \%)$ have a ratio $<16$. The geometric mean and median values of the $\mathrm{NO}_{3}^{-} / \mathrm{PO}_{4}^{3-}$ ratios in this depth interval were 6.1 and 7.8, respectively. Between 150 and $400 \mathrm{~m}$ depth, the $\mathrm{NO}_{3}^{-} / \mathrm{PO}_{4}^{3-}$ ratios were somewhat more constant with geometric mean and median values of 23.8 and 24.9. Similar $\mathrm{NO}_{3}^{-} / \mathrm{PO}_{4}^{3-}$ depth profiles were observed in the core and the boundary of the Cyprus eddy (Krom et al., 1991), where ratios between 2 and 25 were calculated for the upper $100 \mathrm{~m}$ and $27 \pm 4$ below $300 \mathrm{~m}$ (at the boundary).

The $\mathrm{NO}_{3}^{-} / \mathrm{PO}_{4}^{3-}$ ratio appears to vary seasonally in the upper $150 \mathrm{~m}$. During autumn and winter (except March 1998), ratios were relatively low, 2.7 and 4.8 (median values), in comparison with 10.4 and 8.9 in summer and spring (figure 8). Thus, the autumn-winter phytoplankton bloom (highest integrated $\mathrm{Chl} a$ values) was associated with the lowest $\mathrm{NO}_{3}^{-} / \mathrm{PO}_{4}^{3-}$ ratios. It is debatable if the $\mathrm{NO}_{3}^{-} / \mathrm{PO}_{4}^{3-}$ ratios in the euphotic zone are related to phytoplankton uptake of nutrients and/or to the presence of other nutrient phases that were not measured in this study (i.e., dissolved organic phosphorus and nitrogen). It is not clear why the system exhibits $\mathrm{N}$ limitation when both, the upwelling and atmospheric exogenous nutrient inputs have high ( > 16) $\mathrm{NO}_{3}^{-} / \mathrm{PO}_{4}^{3-}$ ratios (Krom et al., 1991; Herut et al., 1999a). If the water mixing is a main factor, we would have expected that the ratios would increase upon mixing with deeper waters of higher $\mathrm{NO}_{3}^{-} / \mathrm{PO}_{4}^{3-}$ ratios $(\sim 24)$. Similarly, atmospheric inputs have also higher $\mathrm{NO}_{3}^{-} / \mathrm{PO}_{4}^{3-}$ ratios (Herut et al., 1999a). If the phytoplankton uptake is close to the Redfield ratio (16:1) and the initial ratio of $\mathrm{NO}_{3}^{-} / \mathrm{PO}_{4}^{3-}$ 
before the blooming was $<16$, the $\mathrm{NO}_{3}^{-} / \mathrm{PO}_{4}^{3-}$ ratio will further decrease. The $\mathrm{NO}_{3}^{-} / \mathrm{PO}_{4}^{3-}$ ratios in particulate organic matter in water layers above the DCM on the continental shelf off Egypt were $\sim 20$ (Abdel-Moati, 1990), suggesting that the $\mathrm{NO}_{3}^{-} / \mathrm{PO}_{4}^{3-}$ ratios there are lower than the Redfield ratio, similar to what we observed. In the DCM layer, the particulate organic $\mathrm{NO}_{3}^{-} / \mathrm{PO}_{4}^{3-}$ ratios were close to the Redfield ratio ( 16) (Abdel-Moati, 1990), but were possibly affected by some preferential remineralization of P. A preferential uptake of nutrients by the phytoplankton may account for such a decrease. Preliminary data of relatively high dissolved inorganic $\mathrm{NO}_{3}^{-} / \mathrm{PO}_{4}^{3-}$ ratios in interstitial waters, > 25 (Herut, unpublished data), may indicate the oxidation of $\mathrm{P}$ depleted organic matter $\left(\mathrm{NO}_{3}^{-} / \mathrm{PO}_{4}^{3-}>16\right)$.

The structure of the phytoplankton population in these sites was not examined and is not well known. Based on numerical abundance counted in a previous study (Kimor et al., 1987), the monads and the coccolithophorids $(<20 \mu \mathrm{m})$ are predominant and dominant in their contribution to the total chlorophyll. However, there was a high spatial variability in the population percentages. Therefore, it remains to be determined if there is preferential uptake producing a fractionated nutrient covariance.

The nutrient phases measured in this study (dissolved inorganic $\mathrm{NO}_{3}^{-}$and $\mathrm{PO}_{4}^{3-}$ ) are probably overwhelming in the deep water, while the surface waters may contain other important phases. Thus, the determination of the possible presence and the contribution of additional nutrient phases is an important next step toward the understanding of nutrient limitation in such ultra-oligotrophic systems.

\section{Acknowledgements}

The authors would like to express their gratitude to L. Izraelov, Y. Gertner, E. Shoam-Frider and E. Shefer for their technical assistance in the sample collection and analyses, and to the crew of the R/V Shikmona. This project was supported by the Geoand Life Sciences Foundation with financial aid from the Netherlands Organisation for Scientific Research, project-number 75019-610A and by the Israeli Ministry of Infrastructure.

\section{REFERENCES}

Abdel-Moati, A.R., 1990. Particulate organic matter in the subsurface chlorophyll maximum layer of the southeastern Mediterranean. Oceanol. Acta 13, 307-315.

Antoine, D., Morel, A., Andre, J.-M., 1995. Algal pigment distribution and primary production in the eastern Mediterranean as derived from coastal zone color scanner observations. J. Geophys. Res. 100, 16193-16209.

Azov, Y., 1986. Seasonal patterns of phytoplankton productivity and abundance in nearshore oligothrophic waters of the Levant Basin (Mediterranean). J. Plankton Res. 8, 41-53.

Berman, T., Townsend, D.W., El Sayed, S.Z., Trees, C.C., Azov, Y., 1984. Optical transparency, chlorophyll and primary productivity in the Eastern Mediterranean near the Israeli coast. Oceanol. Acta 7, 367-371.

Berman, T., Walline, P.D., Schneller, A., Rothenberg, J., Townsend, D.W., 1985. Secchi disk depth record: A claim for the eastern Mediterranean. Limnol. Oceanogr. 30, 447-448.

Berman, T., Azov, Y., Schneller, A., Walline, P.D., Townsend, D.W., 1986. Extent, transparency and phytoplankton distribution of the neritic waters overlying the Israeli coastal shelf. Oceanol. Acta 9, 439-447.

Bethoux, J.P., Morin, P., Chaumery, C., Connan, O., Gentili, B., Ruiz-Pino, D., 1998. Nutrients in the Mediterranean sea, mass balance and statistical analysis of concentrations with respect to environmental change. Mar. Chem. 63, 155-169.

Brezezinsky, M.A., 1985. The $\mathrm{Si} / \mathrm{C} / \mathrm{N}$ ratio of marine diatoms: interspecific variability and the effect of some environmental variables. J. Phycol. 21, 347-357.

Carpenter, J.H., 1965. The Chesapeake Bay Institute technique for the Winkler dissolved oxygen method. Limnol. Oceanogr. 10, $439-447$.

Civitarese, G., Gacic, M., Vetrano, A., Boldrin, A., Bregant, D., Rabitti, S., Souvermezoglou, E., 1998. Biochemical fluxes through the Strait of Otranto (eastern Mediterranean). Cont. Shelf Res. 18, 773-789.

Codispoti, L.A., 1989. Phosphorus vs. nitrogen limitation of new and export production. In: Berger, W.H., Smetacek, V.S., Wefer, G. (Eds.), Productivity of the ocean: Present and past. Dahlem Conferenzen Research Report 44. John Wiley \& Sons Ltd, Chichester, pp. 377-408.

Cullen, J.J., 1982. The deep chlorophyll maximum: comparing vertical profiles of chlorophyll $a$. Can. J. Fish Aquat. Sci. 391, 791-803.

Dortch, Q., Whiteledge, T.E., 1992. Does nitrogen or silicon limit phytoplankton production in the Mississippi river plume and nearby regions? Cont. Shelf Res. 12, 1293-1309.

Dowidar, N.M., 1984. Phytoplankton biomass and primary productivity of the southeastern Mediterranean. Deep-Sea Res. 31, 983-1000.

Eppley, R.W., 1989. New production: history, methods, problems. In: Berger, W.H., Smetacek, V.S., Wefer, G. (Eds.), Productivity 
of the oceans: present and past. Dahlem Conferenzen Research Report 44. John Wiley \& Sons Ltd, Chichester, pp. 85-98.

Fanning, K.A., 1992. Nutrient provinces in the sea: concentration ratios, reaction rate ratios, and ideal covariation. J. Geophys. Res. 97, 5693-5712.

Gitelson, A., Karnieli, A., Goldman, N., Yacobi, Y.Z., Mayo, M., 1996. Chlorophyll estimation in the Southeastern Mediterranaen using CZCS images: adaptation of an algorithm and its validation. J. Mar. Sys. 9, 283-290.

Goldman, J.C., 1993. Potential role of large oceanic diatoms in new primary production. Deep-Sea Res. 40, 159-168.

Hecht, A., Pinardi, N., Robinson, A.R., 1988. Currents, water masses, eddies and jets in the Mediterranean Levantine Basin. J. Phys. Oceanogr. 18, 1320-1353.

Herut, B., Krom, M.D., Pan, G., Mortimer, R., 1999a. Atmospheric input of nitrogen and phosphorus to the SE Mediterranean: sources, fluxes and possible impact. Limnol. Oceanogr. 44, $1683-1692$.

Herut, B., Zohary, T., Robarts, R.D., Kress, N., 1999b. Adsorption of dissolved phosphate onto loess particles in surface and deep eastern Mediterranean water. Mar. Chem. 64, 253-265.

Holm-Hansen, O., Lorenzen, C.J., Holmes, R.W., Strickland, J.D.H., 1965. Fluorometric determination of chlorophyll. J. Cons. Perm. Int. Explor. Mer 30, 2-15.

Ignatiades, L., Georgopoulus, D., Karydis, M., 1995. Description of the phytoplankton community of the oligotrophic waters in the SE Aegean sea (Mediterranean). Mar. Ecol. 16, 13-26.

Johnson, K.S., Chavez, F.P., Friederich, G.E., 1999. Continentalshelf sediment as a primary source of iron for coastal phytoplankton. Nature 398, 697-700.

Justic, D., Rabalais, N.N., Turner, R.E., Dortch, Q., 1995. Changes in nutrient structure of river dominated coastal waters: stoichiometric nutrient balance and its consequences. Estuar. Coast. Shelf Sci. 50, 339-356.

Kemp, A.E.S., Pearce, R.B., Koizumi, I., Pike, J., Rance, S.J., 1999. The role of mat-forming diatoms in the formation of Mediterranean sapropels. Nature 398, 57-61.

Kimor, B., Berman, T., Schneller, A., 1987. Phytoplankton assemblages in the deep chlorophyll maximum layers off the Mediterranean coast of Israel. J. Plankton Res. 9, 433-443.

Krom, M.D., Kress, N., Brenner, S., Gordon, L.I., 1991. Phosphorus limitation of primary productivity in the E. Mediterranean sea. Limnol. Oceanogr. 36, 424-432.

Krom, M.D., Brenner, S., Kress, N., Neori, A., Gordon, L.I., 1992. Nutrient dynamics and new production in a warm-core eddy from the eastern Mediterranean. Deep-Sea Res. 39, 467-480.

Krom, M.D., Brenner, S., Kress, N., Neori, A., Gordon, L.I., 1993. Nutrient distributions during an annual cycle across a warm-core eddy from the eastern Mediterranean sea. Deep-Sea Res. 40, $805-825$.
Milliman, J.O., 1991. Flux and fate of fluvial sediment and water in coastal seas. In: Mantoura, R.F.C., Martin, J.M., Wollast, R. (Eds.), Ocean Margin Processes in Global Change. John Wiley \& Sons Ltd, Chichester, pp. 69-89.

Oren, O.H., Komarovsky, B., 1961. The influence of the Nile flood on the shore waters of Israel. Rapp. Comm. Int. Mer. Medit. 16, $655-659$.

Ozsoy, E., Hecht, A., Unluata, U., Brenner, S., Sur, H.I., Bishop, J., Latif, M.A., Rozentraub, Z., Oguz, T., 1993. A synthesis of the Levantine Basin circulation and hydrography 1985-1990. Deep-Sea Res. II 40, 1075-1119.

Parsons, T.R., Takahashi, M., Hargrave, B., 1977, 332 pp.. Biological Oceanographic Processes, 2nd edn. Pergamon Press, Oxford.

POEM Group, 1992. General circulation of the Eastern Mediterranean. Earth-Science Reviews 32, 285-309.

Rosentraub, Z., 1995. Circulation on the Mediterranean continental shelf and slope of Israel. IAEPSO 21 General Assembly, Honolulu, Hawaii, 5-12 August 1995.

Salihoglu, I., Saydam, C., Basturk, O., Yilmaz, K., Gocmen, D., Hatipoglu, E., Yilmaz, A., 1990. Transport and distribution of nutrients and chlorophyll-a by mesoscale eddies in the northeastern Mediterranean. Mar. Chem. 29, 375-390.

Sancetta, C., Villareal, T., Falkowski, P., 1991. Massive fluxes of Rhizosolenid diatoms: a common occurrence? Limnol. Oceanogr. 36, 1452-1457.

Schneller, A., Kimor, B., Azov, Y., 1984. Seasonal distribution of diatoms and dinoflagellates ( $>65 \mu \mathrm{m}$ ) off the coast of Israel. XXIXth Congress and Plenary Assembly, Lucerne, Plankton Committee, Rapp. PV Reun. CIESM, October 11-19, 1984.

Sharaf El Din, S.H., 1977. Effect of Aswan High Dam on the Nile flood and on the estuarine and coastal circulation pattern along the Mediterranean Egyptian coast. Limnol. Oceanogr. 22, 194207.

Thingstad, T.F., Rassoulzadegan, F., 1995. Nutrient limitations, microbial food webs and 'biological C-pump': suggested interactions in a P-limited Mediterranean. Mar. Ecol. Prog. Ser. 117, 299-306.

Van Dijken, G.L., Arrigo, K.R., 1996. Ocean color remote sensing of the southeastern Mediterranean Sea. EOS 76, 167.

Villareal, T.A., 1991. Nitrogen-fixation by the cyanobacterial symbiont of the diatom genus Hemiaulus. Mar. Ecol. Prog. Ser. 76, 201-204.

Yacobi, Y., Zohary, T., Kress, N., Hecht, A., Robarts, R.D., Wood, A.M., Li, W.K.W., 1995. Chlorophyll distribution throughout the southeastern Mediterranean in relation to the physical structure of the water mass. J. Mar. Sys. 6, 179-190.

Zohary, T., Robarts, R.D., 1998. Experimental study of microbial $\mathrm{P}$ limitation in the eastern Mediterranean. Limnol. Oceanogr. 43, 387-395. 